Executive Letter

\title{
Financial Democratization in Pandemic Times
}

\section{Democratização Financeira em Época de Pandemia}

The Zumbi dos Palmares University (Unipalmares), founded in 2002 by academics, liberal professionals, intellectuals, and personalities from several areas of knowledge, is a non-profit community higher education institution, whose mission is to train and include qualified professionals, committed to ethic values, human dignity, and racial-ethnic diversity. It also aims to include and strengthen the presence of young black people in the academic world, in the labor market, and in the general society, as well as to research, promote, disseminate, and refine public and private affirmative actions and the culture of peace, tolerance, and peaceful conflict resolution.
We are an institution that strives for the highest aspect of universal democratization, which is education access and everything surrounding it. We seek to fill a gap in Brazilian society by exerting education as the only tool that truly leads to full freedom. We train not only the professional but also, and above all, the protagonist citizen responsible for his path. This same individual will be capable to make life decisions most consistently and rationally, without the tutelage of state, family, and influencers of all sorts. The freedom conquered by education prepares human beings for the world's complexities, develops their potentialities, and makes them complete and elevated. 
The assumption of the Zumbi dos Palmares University's work is to include and integrate a share of the population that faces many difficulties concerning access to qualified higher education, preparing these young people mainly as thinking beings, critics of reality, and prepared for social and professional challenges of the current world. Our institution is an integrator, a reconciler of social concerns, and worried about equality of opportunities. We offer nine undergraduate courses and we have already trained nearly three thousand students in several fields. We reserve half of the available places to afro-descendants and half to students of other ethnic backgrounds, clearly showing our intention to integrate and diversify our student body. The same goes for teaching staff: half of our professors are afro-descendants, a unique phenomenon in the Brazilian educational market, where there are 2,608 higher education institutions (Instituto Nacional de Estudos e Pesquisas Educacionais Anísio Teixeira [Inep], 2019), in a country where black people make up $56 \%$ of the population (Instituto Brasileiro de Geografia e Estatística [IBGE], 2019). For comparative effect, in the USA, where only $13 \%$ of the population is black, there are $101 \mathrm{HBCUs}$, or historically black colleges and universities (Anderson, 2017).

This internal diversity is a source of great pride, but at the same time, it dismays us in front of what happens outside our walls, in other companies, public and private organs, and all social spheres.

Since March 2020, with the COVID-19 pandemic, we need to quickly reinvent ourselves to keep educational activities in appropriate conditions for the moment, without a loss for our students, teachers, employees, and the general community. This rupture in the academic world follows the transformation that has been happening all over the world and in the market, where we see organizations adapting to what has been called the 'new normal.'

For many, the expression 'new normal' means a subtle difference, but, unhappily, for us, black people, there is nothing quite different from what we always lived; the pandemic served to unmask contradictions and the social abyss that keep us apart of other societal segments. In all aspects, black population social indicators are terrible. Blacks are hit hardest by unemployment, precariousness or lack of housing and basic sanitation, coronavirus contamination, and the difficulties in developing remote work, by school abandonment, discouragement, and emotional frustration, among other factors that underlie full citizenship. Therefore, the 'new normal' only aggravated black population exclusion, which was already dramatically excluded from a dignified life.

Considering the showcased scenario and its implications for the black community, we highlight that the solution for this social malaise involves awareness of black people about their real condition of existence and intensification of tools for their educational and professional formation offered by our institution.

The Zumbi dos Palmares University's motto is "Without education, there is no freedom," and this principle guides all of our initiatives, sustains our convictions, and moves us toward the future. Our path is to transform black people's lives, reframe their past, and build a better future through education. But we understand that, alongside education, we must rescue a lot of black population history, their artistic expression, their place in the world, and their historical breadth. Thus far, we have partnership with companies that allow us to place young people in the labor work and practical professional formation, we promote events of recognition of expressive actions in the fight against racial prejudice and affirmative actions, we organize literary events with the protagonism of black authors, and we have developed research on the condition of blacks in the labor market, among other initiatives of the Observatory of the Black. In other words, education is the main line that articulates all these actions to rescue and valorize black production, with emphasis on our participation in the social construction, reinforcing its identity and self-esteem.

Much has been said about the necessity to democratize Brazilian society, but the most diverse spheres of social activity lack mechanisms of universalization or equitable access and, consequently, of decentralized and plural opportunities. The superficial treatment of this aspect leads to an abstraction of what really would be democratization and which would be its consequences.

Real societal democratization involves access to all aspects of complete citizenship. Education is amongst the main ones, but it is not the only one. To change this current situation, we need financial resources for the social development and generation of jobs and income. In this regard, we observed a change in the financial market, induced by the increase in the number of actors and the entry of new players, exemplified by digital banks, by fintechs (startups of the financial segment), by direct credit societies, by normative simplification of the Central Bank, and by the support given by Febraban, a representative entity of Brazilian banking sector. The competition is positive and implies earnings for all market participants, leveraging innovation, creativity, and better marketing practice.

The current market has suffered ruptures, and a new structure is being imposed based on mobilecentrism, grounded on automation, artificial intelligence, and agility, which will enable an increase in the productivity of professionals of the segment, acquisition, and engagement of consumers, transforming these consumers in one of the engines of compliance, and relationships will be established with fintechs and other companies that use digital platforms. 
We observed a significant increase of initiatives in the financial market; according to Brazilian Central Bank data - Banco Central do Brasil (2020), there are already 20 digital banks, but none specifically aimed at the black public. Although the market discourse emphasizes the personalization experience for the banking customer, what happens is the massification, focused on offering standardized products and services, aiming at reducing costs, encouragement of selfservice, and with a great deficiency in guidance and advice for costumers to make better use of accessed resources.

The pandemic managed to accelerate everything, including our determination to make the black population bankable, allowing entrepreneurs to take the leading role in their business initiatives. We understand this is the right moment to lay the foundations of a socioeconomic transformation through financial education and protagonism of a financial institution capable of understanding the singularities and susceptibilities of this population, and providing black entrepreneurs access to necessary resources.

According to a survey carried out by Locomotiva Institute - Instituto Locomotiva (2019), 31.5 million black people are unbanked, and a significant portion of them does not have access to cell phones, computers, or the internet. On the other hand, they need financial services to support their growth, thrive, and conquer the desired sustainability.

In this context, we consider it essential to establish a financial institution that aims to attend the black entrepreneur, standing out for financial education, easier access to credit, guidance in resources utilization, and above all, comprehension of specific difficulties of this population. And, as a contribution to the theme of Brazilian society democratization, financial market, and support to the black population, we make public the launching of BankZ, "the bank of blacks of all colors." This initiative was born as a digital platform linked to the Zumbi dos Palmares University and will make financial intermediation with facilitated credit and microfinance services for small enterprises, which tends to promote initiatives of this population. According to Instituto Locomotiva (2019), the unbanked population in the country moves around $\mathrm{R} \$ 817$ billion annually, 59\% of this contingent is made by women, $75 \%$ of the public avoids resorting to traditional banks, and $88 \%$ do not possess credit cards. Evidently, it is a market segment that deserves to be studied and comprehended, and institutions must seek disruptive solutions, personalized, appropriate to this public's market needs, and break with the standard concept of financial treatment.

By the way, we launched some provocations and challenges to academics in the administration area, especially from the financial field, so that they develop studies aiming to unveil circumstances and situations that deserve more attention:

- What are the reasons for the resistance of the traditional financial model to work with the black public?

- Does the number of successful experiences with microcredit match the size of this market?

- Are there new operating models to enhance the economic and financial development of black people?

- Do traditional financial markets work or are there prejudice and mental models inhibiting disruptive action proposals?

- What are the real reasons why a great part of the public avoids traditional bank models and end up bearing the burden of informality?

- Is the difficulty for banks to provide guidance/advice to this audience due to the low level of education of people or due to the inefficiency of institutions in preparing professionals with this capacity?

- Why in Brazil, so far, we do not have a bank that operates with an ethnic-racial approach giving priority to the black population?

Finally, hoping to compete for the financial market democratization, apparently pursued and encouraged by regulatory organs, we will serve a public in need of a financial institution that really represents and understands their primary needs, we will contribute to job and income generation and decreasing of the economic and social abyss of the black population. Surely, in a short time, we will expand the discussion with invisible and little-studied data, which is the number and history of economically well-succeeded black people in Brazil. 


\section{REFERENCES}

Anderson, M. (2017, February) A look at historically black colleges and universities as Howard turns 150. Factank - News in the Numbers. Retrieved from https://www.pewresearch.org/facttank/2017/02/28/a-look-at-historically-black-colleges-anduniversities-as-howard-turns-150/

Banco Central do Brasil. (2020). Fintechs de crédito e bancos digitais. Estudo especial no. 89/2020. Retrieved from https://www.bcb. gov.br/conteudo/relatorioinflacao/EstudosEspeciais/EE089 Fintechs de credito e bancos digitais.pdf

Instituto Brasileiro de Geografia e Estatística. (2019). Pesquisa nacional por amostra de domicilios continua - PNAD contínua. Retrieved from https://www.ibge.gov.br/estatisticas/ sociais/trabalho/9171-pesquisa-nacional-por-amostra-dedomicilios-continua-mensal.html? =\&t=0-que-e
Instituto Nacional de Estudos e Pesquisas Educacionais Anísio Teixeira. (2019). Notas estatísticas 2019. Censo da educação superior 2019. Retrieved from https://download.inep.gov. br/educacao_superior/censo_superior/documentos/2020/ Notas Estatisticas Censo da Educacao Superior 2019. pdf

Instituto Locomotiva (2019, September). Um em cada três brasileiros não tem conta em banco, mostra pesquisa Locomotiva. Retrieved from https://www.ilocomotiva.com.br/single-post/2019/09/24/ um-em-cada-tr\%C3\%AAs-brasileiros-n\%C3\%A3o-temconta-em-banco-mostra-pesquisa-locomotiva

\section{AUTHORSHIP}

\section{José Vicente}

Universidade Zumbi dos Palmares

Av. Santos Dumont, 843, Bom Retiro, 01101-000, São Paulo, SP, Brazil.

E-mail address: jose.vicente@zumbidospalmares.edu.br

(D) https://orcid.org/0000-0001-6829-0647

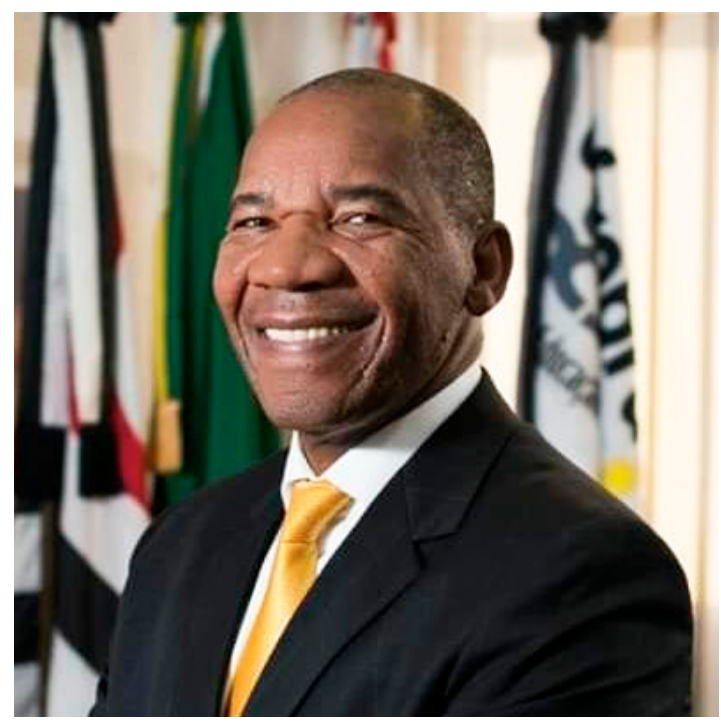

Lawyer, he holds a $\mathrm{PhD}$ in Education and a Master of Business Administration from UNIMEP - Universidade Metodista de Piracicaba, in São Paulo, as well as is a Master of Law from Escola Paulista de Direito. He is founder and Dean of the Zumbi dos Palmares University, president and founder of the Afrobrazilian Society of Socio Cultural Development - Afrobras, founder and holder of the Movimento Todos Pela Educação (All for Education Movement), founder of the Business Initiative for Racial Equality, founder of Virada da Consciência (Turn of Consciousness), founder of the Air Movement - Black lives matter. Member of the Judicial Research Council of the CNJ - Brazilian National Council of Justice, Member of the USP's Inclusion Policy Monitoring Committee, Member of the Economic and Social Development Council of the Brazilian Presidency of the Republic, President of the Management Council of the Human Rights and Citizenship Secretariat of São Paulo, Member of the Curator Council of the Fundação Memorial da América Latina (Memorial Foundation of Latin America), Member of the Superior Council for Advanced Studies of FIESP, Member of LIDE - Business Leaders, Vice President of the Truth Commission on Slavery of OAB (Brazilian Bar Association), former member of the Board of Trustees of Fundação Cultural Palmares of the Brazilian Ministry of Culture, former member of the Management Council of the City Council of São Paulo, former member of the Deliberative Council of the Ethos Institute for Business Responsibility, former member of the Board of FEBRABAN - Brazilian Federation of Banks, former member of the Advisory Board of the Center for Integration between School and Business - CIEE, member of the Black Lawyers Commission of the Chamber of Deputies and Author of the book "Discursos Afirmativos" (Affirmative Speeches) published by Editora Unipalmares in 2018 . 


\section{Valdir Martins*}

Universidade Zumbi dos Palmares

Av. Santos Dumont, 843, Bom Retiro, 01101-000, São Paulo, SP, Brazil.

E-mail address: valdir.martins@zumbidospalmares.edu.br

(D) https://orcid.org/0000-0003-2900-1931

* Corresponding Author.

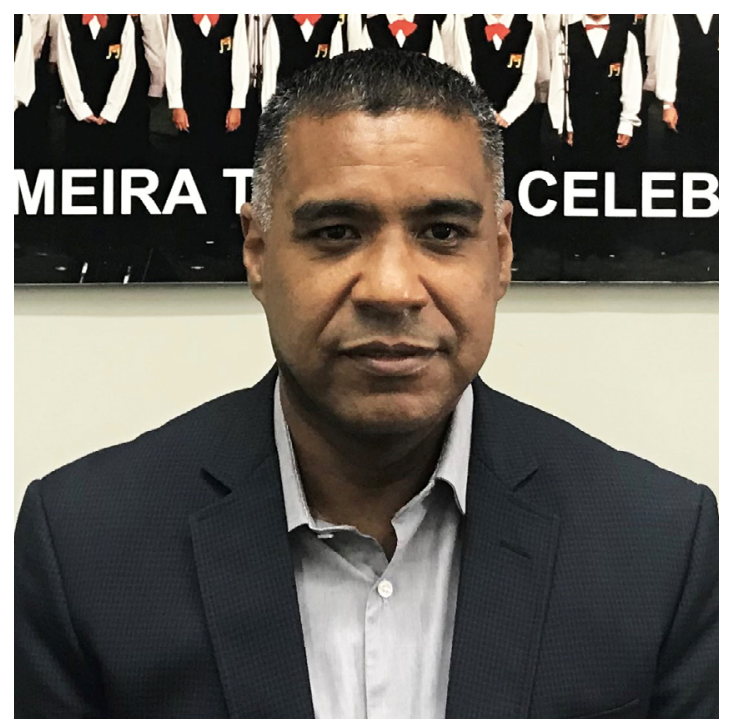

Coordinator of Graduate Studies, Research and Extension at the Zumbi dos Palmares University, Coordinator of the Data Zumbi Institute, University Professor. 35 years of experience in the financial market (Banco do Brasil), Tax Advisor of APABB, Post-Doctorate in Public Administration and Government by FGV / EAESP, Doctorate in Communication and Semiotics by PUC-SP, Master in Communication and Market by Fundação Cásper Líbero, Bachelor of Social Sciences from USP. Specialization in Social Communication Administration, Marketing and Advertising, Specialization in Business Management, Specialization in Social Policy and Combating Poverty, Specialization in Political Science, Specialization in New Technologies in Marketing and Communications from the University of Florida, and MBA in Finance for Management and Business Development by USP / FIA.

\section{Conflict of Interests}

The author have stated that there is no conflict of interest.

\section{Copyrights}

RAC owns the copyright to this content.

\section{Plagiarism Check}

The RAC maintains the practice of submitting all documents approved for publication to the plagiarism check, using specific tools, e.g.: iThenticate.

Note: Executive Letters are documents published since January 2021 by the Journal of Contemporary Administration (Revista de Administraçáo Contemporânea), and serve the role of enabling and establishing dialogue between the community of practitioners and the academic community in the field of business and management. The main intention of publishing the Executive Letters is to consolidate and guide the social impact of scientifically rigorous research in this field. These documents must contain, as a priority, the opinion, at the individual level, of people who exercise leadership in sectors of industry or public management about problems relevant to their performance. To that end, these documents should address contexts and problems faced by leaders, who can be reflected in a research target in the business and management area. The Executive Letters will be authored by individuals invited by RAC Editors. 


\section{WHAT IS THE JOURNAL OF CONTEMPORARY ADMINISTRATION?}

The Journal of Contemporary Administration (Revista de Administração Contemporânea - RAC) was established in 1997 and is published bimonthly (continuous publication) by ANPAD (Brazilian Academy of Management), with openaccess to its full text (peer-reviewed) content online. Registered under ISSN 1982-7849 (online) and ISSN 1415-6555 (print version from 1997 to 2010). The journal publishes articles on theoretical development and theoretical-empirical work in the area of Administration and Accounting, aligned with Open Science practices: open data, materials and open source, as well as the dissemination of additional information related to the editorial process. This journal is a member of, and subscribes to the principles of, the Committee on Publication Ethics (COPE) for scholarly publication. The Journal of Contemporary Administration (RAC) is the leading academic journal in its field, with high quality peer-reviewed contributions. Therefore, we pay special attention to the role of RAC: to be a reliable source of data, information, and knowledge. In addition, RAC, through its editorial scope, prioritizes works that explore themes relevant to society. To do so, it uses the themes highlighted in the UN Sustainable Development Goals (SDGs). RAC is a pluralistic and unorthodox business journal in the field of management research, primarily concerned with issues relating to the links between strategy and competitive management, and provides research findings on systems and standards, corporate management tools, organizations and management, specific industry sectors, and answers to contemporary issues such as development, community resilience, inequality, consumption, technology, and climate change.

\section{Indexers and Directories}

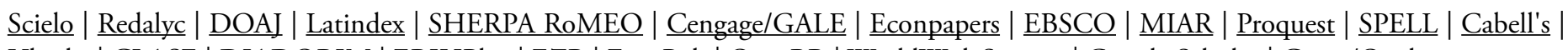

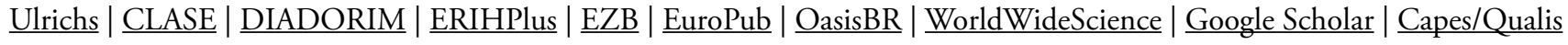

